Print ISSN: 2288-4637 / Online ISSN 2288-4645

doi:10.13106/jafeb.2020.vol7.no11.1033

\title{
Analysing Productivity Change in Vietnamese Garment Industry Using Global Malmquist Index
}

\author{
Thanh Khac MAI ${ }^{1}$, Van NGUYEN², Trang Huyen Thi VU ${ }^{3}$ \\ Received: August 01, 2020 Revised: September 30, 2020 Accepted: October 15, 2020
}

\begin{abstract}
Vietnam is conducting an export-led growth model and labour-intensive industries contributing majorly to the total export value. In the context of Industry 4.0, the labour-based industries are significantly affected; hence, enhancing productivity is the key measure to maintain these industries. The garment industry contributes significantly to the total export value of Vietnam. Based on meta-frontier framework, the approach of data envelopment analysis is used to measure technical efficiency of Vietnamese garment firms and the global Malmquist TFP index is utilised to identify productivity change and its components including efficiency, technology and technical gaps between different groups of firms. The data of Vietnamese garment firms from 2013 to 2018 collected from the Vietnam General Statistic Office is used in this study. The results show that: (i) The total factor productivity of Vietnamese garment firms growth, technical progress is the main contributor; (ii) The private garment sector is the leading group; (iii) There is a large technological gap among Vietnamese garment sectors. The private and FDI garment firms have experienced a growth in all components of total factor productivity change. Meanwhile, technological progress change is the main reason to constrain the productivity growth of state-owned garment firms.
\end{abstract}

Keywords: Data Envelopment Analysis, Global Malmquist Total Factor Productivity Index, Meta-Frontier, Technical Efficiency

JEL Classification Code: C6, D24, O14, O47

\section{Introduction}

In recent years, Vietnam has accelerated its integration into the world economy by signing new free trade agreements (FTAs), such as Comprehensive and Progressive Agreement for Trans-Pacific Partnership (CPTPP), VietnamEurope Union FTA, Vietnam-South Korean FTA, VietnamASEAN FTA (Nguyen et al, 2020). This strategy advocates the export-led growth model of Vietnam whereas labour-

${ }^{1}$ First Author. Vine Dean, Faculty of Management and Finance, Vietnam Maritime University, Vietnam.

Email: mkthanh@vimaru.edu.vn

${ }^{2}$ Corresponding Author. Lecturer, Faculty of Fundamental Science, Vietnam Maritime University, Vietnam [Postal Address: 484 Lach Tray Street, Le Chan District, Haiphong, 180000, Vietnam]

Email: vanxpo@vimaru.edu.vn

${ }^{3}$ Lecturer, Department of Mathematics, Thuongmai University, Vietnam. Email: trang.vth@tmu.edu.vn

(c) Copyright: The Author(s)

This is an Open Access article distributed under the terms of the Creative Commons Attribution Non-Commercial License (https://creativecommons.org/licenses/by-nc/4.0/) which permits unrestricted non-commercial use, distribution, and reproduction in any medium, provided the original work is properly cited. intensive industries are the most beneficial (Nguyen et al., 2019; Le et al, 2020).

However, these industries face a number of challenges. The first challenge is from the Industrial Revolution 4.0 in which labourers are possibly replaced by machines and equipment. Consequently, temporary labour-intensive industries will become automatic and require only a small number of labourers. The second is from the competitors in other Asian countries including India, and Bangladesh (Tran, 2012). These countries have also intensified their global connection and have more abundant and cheaper labour forces. To solve these problems and remain competitive, the key solution for Vietnam is to continuously improve the productivity in labour-incentive areas before replacing these low-tech industries by hightech industries.

Textile and garment are the most important labourintensive industries in Vietnam by mainly contributing to the country's export and economic growth over the last three decades. According to the statistics data of the Vietnam Textile and Garment Association, the average growth rate of export value in the last 5 years stands at $14.74 \%$ per 
year and export turnover in 2018 was 36.2 billion USD, accounting for $16 \%$ of Vietnam industrial production value. The textile and garment is the second largest export item of the country following telephone and telephone accessories (Ministry of industry and trade, 2019). Having more than 6,000 large firms and SMEs, the textile and garment industries in Vietnam have created 5\% of jobs and accounted for approximately 2.5 million labourers. Vietnam has been ranked at the 4th position among the largest textile and garment exporters in the world (after China, India and Bangladesh) (Tran, 2012).

Although the textile and garment industries play an important role in the development of the economy, the performance of these sectors in recent years has not met their potential. Foreign direct investment (FDI) in textile and garment firms are more advantageous than domestic rivals due to their better production integration and receiving privileges from the policy of foreign investment (Nguyen, 2020). FDI in textile and garment industry firms accounts for less than $20 \%$ of firms operating in the Vietnamese industry and employs only $4 \%$ of the total workforce, still they dominate the total export value from Vietnam at $70 \%$ while both state-owned and private enterprises contribute the minority towards the exports from the country (Ngo and Tarko, 2018). It is widely accepted that state-owned firms face difficulties in governance due to the problem of agency; however, they can access financial and land resources more easily than other firms. Private firms are almost small and medium; as a result, they cannot exploit the scale effectively and are more vulnerable to external shocks.

The above-mentioned issues on the textile and garment firms in Vietnam point out distinctive production conditions of three firm types belonging to different ownerships (FDI, state-owned and private). According to O'Donnell et al., (2008), disparities in the characteristics of the physical, social and economic environment in which production takes place can result in different technology sets, which are the feasible input-output combinations faced by firms in several industries, regions and/or countries. In order to overcome these drawbacks, this study will analyse efficiency and productivity of Vietnamese garment firms by using the meta-frontier approach and the global Malmquist total factor productivity (TFP) index. Each type of garment firms (stateowned, private and FDI) are considered to have a different production set (technology). Accordingly, productivity change and its components including efficiency change, technical change and technological gap of Vietnamese garment firms are estimated.

Using the meta-frontier approach and the data of the garment industry in Vietnam from 2013-2018, the study shows that the productivity of Vietnamese garment industry has grown and this growth is due to technical progress. The private firms with the most advanced technology are leading the garment industry and contribute mainly to this industry's growth.

The structure of the paper is as follows. Section 2 presents a methodology of meta-frontier and Data Envelopment Analysis. Section 3 describes the data and specifies inputs/ outputs. An analysis of the empirical results is given in Section 4. Finally Section 5 concludes and highlights the key findings.

\section{Methodology}

The concept of meta-frontier was proposed by Hayami (1969), Hayami and Ruttan (1970). Since then, Battese et al $(2002 ; 2004)$ have developed a meta-frontier approach to estimate technical efficiency, technical change and total factor productivity change. The meta-frontier approach can be applied in both data envelopment analysis (DEA) and stochastic frontier analysis (SFA) frameworks.

Up to now, not only Vietnam but also many other countries in the world have studied in different economic sectors using the DEA approach to estimate meta-frontier. For example, Rao et al (2003), O'Donnell et al (2008) used the DEA approach to analyse differences in agricultural productivity of 97 countries in Asia, Europe, America and Africa. Alexandra and Kostas (2010) studied about the effectiveness of cooperative banking in Europe. Wang et al (2013) analysed energy efficiency among provinces in China. Quan (2011) used the DEA approach and metatechnology ratio (MTR) to estimate the technical efficiency of three rice monocultures and two crop rotations in Tra Vinh province. Ho (2016) studied technical efficiency, factor productivity and technological gap between agricultural areas of Vietnam, etc. Figure 1 below presents a definition of technical efficiencies in meta-frontier and group frontiers.

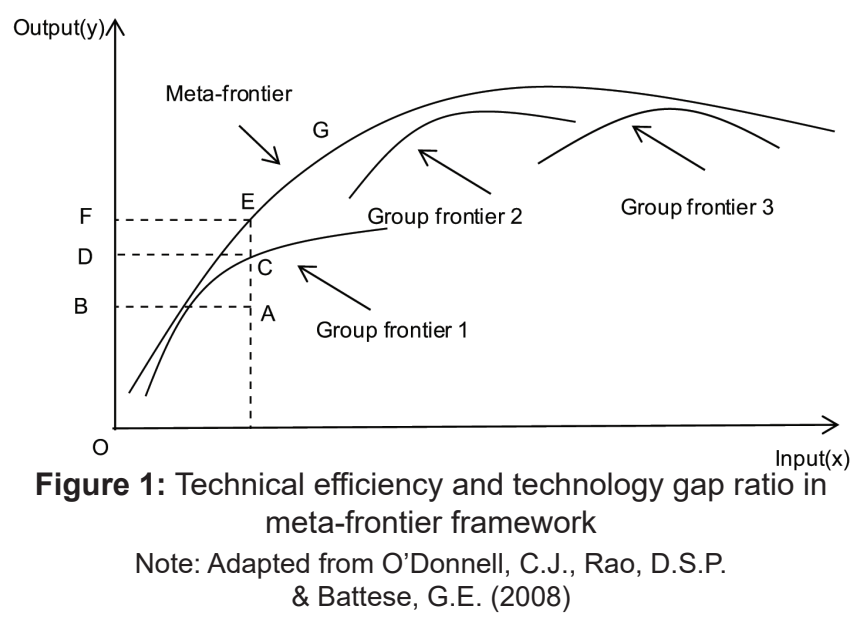


Let's consider firm A in the group 1, there are two measures of technical efficiency that can be derived. Firstly, technical efficiency with respect to meta-frontier. It is defined by using concept of output oriented distance function and using meta-frontier:

$$
T E(x, q)=D_{o}(x, q)=O B / O F
$$

Secondly, using the group frontier to define technical efficiency.

$$
T E^{k}(x, q)=D_{o}^{k}(x, q)=O B / O D
$$

Where $T E(x, q)$ is always less than or equal $T E^{k}(x, q)$

The Figure 1 shows that there is a gap between metafrontier and group frontiers, which reflects the backwardness between group technology and meta-technology. This gap is measured by the concept of technology gap ratio (TGR) (Battese et al. 2004).

The output orientated technology gap ratio $(T G R)$ for group $k^{\text {th }}$ is defined as:

$$
T G R^{k}(x, q)=\frac{D_{o}(x, q)}{D_{o}^{k}(x, q)}=\frac{T E(x, q)}{T E^{k}(x, q)}
$$

The formula (3) can be re-written as:

$$
T E(x, q)=T E^{k}(x, q) \cdot T G R^{k}(x, q)
$$

The formula (4) shows that technical efficiency with respect to meta-frontier consists of two components: Firstly, the current knowledge of production, natural environment, and socio-economic conditions of each group $\left(T E^{\mathrm{k}}\right)$. Secondly, the technology gap of each group over the whole industry (O'Donnell et al. 2008). Oh and Lee (2010) proposed the concept of technology gap change (TGC) to measure the trend of technology gap ratio as:

$$
T G C=\frac{T G R_{t+1}}{T G R_{t}}
$$

$T G C>1$ means the production technology gap of groups is getting closer.

Unlike traditional DEA studies that focus only on efficiency and technological gap at a specific time. The global Malmquist TFP index was proposed by Pastor and Lovell (2005) and developed by Oh and Lee (2010) to measure change in the technical efficiency, technical change and productivity growth. The Figure 2 describes concept of the global Malquist TFP as:

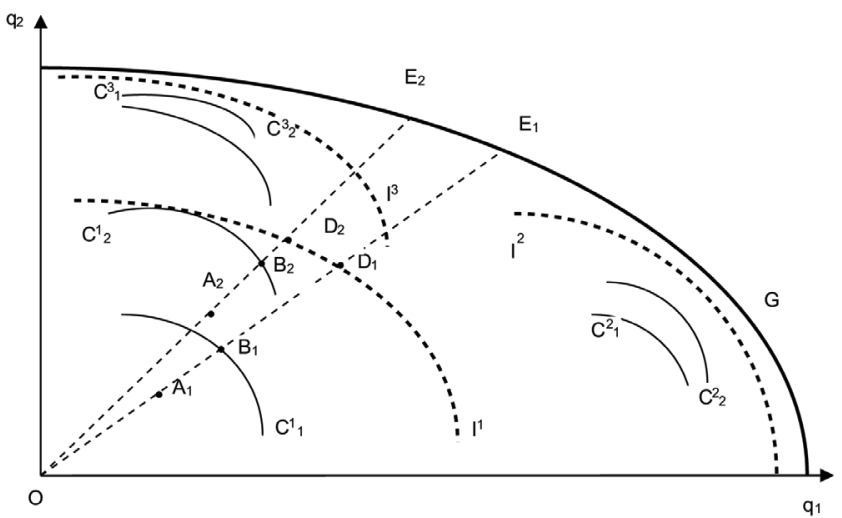

Figure 2: The concepts of the meta-frontier Malmquist indexes

Note: Adapted from Oh, D.H. \& Lee, J.D. (2010)

Where $\mathrm{C}_{j}^{\mathrm{i}}$ are contemporaneous frontiers of groups at a specific time, $\mathrm{I}^{\mathrm{i}}$ are inter-temporal frontiers for groups and there is only one global frontier $\mathrm{G}$.

The common contemporaneous Malmquist TFP index of an observation within group $k^{\text {th }}$ is defined at technology of periods $t$ and $t+l$ as:

$$
M_{C}\left(x^{t}, q^{t}, x^{t+1}, q^{t+1}\right)=\sqrt{\frac{D_{t+1}\left(x^{t+1}, q^{t+1}\right)}{D_{t+1}\left(x^{t}, q^{t}\right)} \times \frac{D_{t}\left(x^{t+1}, q^{t+1}\right)}{D_{t}\left(x^{t}, q^{t}\right)}}
$$

Where $M_{C}$ is Malmquist TFP index, $D_{t}($.$) is the output$ orientated distance function with respect to frontier of period $t$.

The inter-temporal Malmquist TFP index of an observation for each group is defined as:

$$
M_{I}\left(x^{t}, q^{t}, x^{t+1}, q^{t+1}\right)=\frac{D^{I}\left(x^{t+1}, q^{t+1}\right)}{D^{I}\left(x^{t}, q^{t}\right)}
$$

Where $M_{I}$ is an inter-temporal Malmquist TFP index, $D^{I}($.$) is output orientated distance function with respect to$ the inter-temporal frontier of group $I$.

Following Pastor and Lovell (2005), this index can be decomposed as:

$$
\begin{aligned}
M_{I}\left(x^{t}, q^{t}, x^{t+1}, q^{t+1}\right)=\frac{D_{t+1}\left(x^{t+1}, q^{t+1}\right)}{D_{t}\left(x^{t}, q^{t}\right)} \\
\times\left\{\frac{D^{I}\left(x^{t+1}, q^{t+1}\right)}{D_{t+1}\left(x^{t+1}, q^{t+1}\right)} \times \frac{D_{t}\left(x^{t}, q^{t}\right)}{D^{I}\left(x^{t}, q^{t}\right)}\right\}
\end{aligned}
$$


Due to $D_{t+1}\left(x^{t+1}, q^{t+1}\right) / D_{t}\left(x^{t}, q^{t}\right)=T E^{t+1} / T E^{t}=T E C$, the first component in the formula (8) measures technical efficiency change. $D^{I}(x, q) / D(x, q)$ is Best Practice Gap $(B P G)$ as constructed by Pastor and Lovell (2005) and Oh and Lee (2010). BPG is ratio of output orientated distance function with respect to inter-temporal frontier over output orientated distance function with respect to contemporaneous frontier and takes the value in $[0 ; 1]$

$$
B P G^{t}=\frac{D^{I}\left(x^{t}, q^{t}\right)}{D_{t}\left(x^{t}, q^{t}\right)} ; B P G^{t+1}=\frac{D^{I}\left(x^{t+1}, q^{t+1}\right)}{D_{t+1}\left(x^{t+1}, q^{t+1}\right)}
$$

$B P G^{t+1}>B P G^{t}$ describes technological improvements from period $t$ to period $t+1$.

We will use this to describe the concept of Best Practice Gap Change $(B P C) . B P C$ that measures technical change is defined in the global Malmquist TFP index framework in the flowing way:

$$
\begin{aligned}
B P C & =\frac{D^{I}\left(x^{t+1}, q^{t+1}\right)}{D_{t+1}\left(x^{t+1}, q^{t+1}\right)} / \frac{D^{I}\left(x^{t}, q^{t}\right)}{D_{t}\left(x^{t}, q^{t}\right)} \\
& =\frac{D^{I}\left(x^{t+1}, q^{t+1}\right)}{D_{t+1}\left(x^{t+1}, q^{t+1}\right)} \times \frac{D_{t}\left(x^{t}, q^{t}\right)}{D^{I}\left(x^{t}, q^{t}\right)}
\end{aligned}
$$

In summary, inter-temporal Malmquist TFP index can be defined as:

$$
M_{I}\left(x^{t}, q^{t}, x^{t+1}, q^{t+1}\right)=T E C \times B P C
$$

Following Oh and Lee (2010), because output orientated distance function is homogeneous of degree one in output, each $\lambda \in \mathbb{R}$ then $\lambda D(x, q)=D(x, \lambda q)$. Therefore, the formula (11) can be re-written as:

$$
B P C=\frac{D^{I}\left(x^{t+1}, q^{t+1} / D_{t+1}\left(x^{t+1}, q^{t+1}\right)\right)}{D^{I}\left(x^{t}, q^{t} / D_{t}\left(x^{t}, q^{t}\right)\right)}
$$
as:

Similarly, the global Malmquist TFP index is constructed

$$
M_{G}\left(x^{t}, q^{t}, x^{t+1}, q^{t+1}\right)=\frac{D^{G}\left(x^{t+1}, q^{t+1}\right)}{D^{G}\left(x^{t}, q^{t}\right)}
$$

Where $D^{G}\left(x^{t}, q^{t}\right)$ is the output orientated distance function with respect to the meta-frontier. Because there is only a meta-frontier in period $t$ to $t+1$, the formula (13) is not in the geometric mean form. We can decompose $M_{G}$ into the following components:

$$
\begin{aligned}
M_{G}\left(x^{t}, q^{t},\right. & \left.x^{t+1}, q^{t+1}\right)=T E C \times B P C \\
& \times\left\{\frac{D^{I}\left(x^{t}, q^{t}\right)}{D^{I}\left(x^{t+1}, q^{t+1}\right)} \times \frac{D^{G}\left(x^{t+1}, q^{t+1}\right)}{D^{G}\left(x^{t}, q^{t}\right)}\right\}
\end{aligned}
$$

According to the concept of technology gap ratio has been introduced above we have:

$$
\begin{gathered}
T G R_{t+1}=\frac{D^{G}\left(x^{t+1}, q^{t+1}\right)}{D^{I}\left(x^{t+1}, q^{t+1}\right)} ; T G R_{t}=\frac{D^{G}\left(x^{t}, q^{t}\right)}{D^{I}\left(x^{t}, q^{t}\right)} ; \\
T G C_{t, t+1}=\frac{T G R_{t+1}}{T G R_{t}}
\end{gathered}
$$

Therefore, the formula (14) can be re-written as:

$$
M_{G}\left(x^{t}, q^{t}, x^{t+1}, q^{t+1}\right)=T E C \times B P C \times T G C
$$

This formula implies that the following steps can be implemented to increase total factor productivity: Effective exploitation of existing production resources; Technological improvements within groups; Improvement the technology of industry.

Because output orientated distance function is homogeneous, (14) can be re-written as:

$$
\begin{aligned}
& M_{G}\left(x^{t}, q^{t}, x^{t+1}, q^{t+1}\right)=\frac{D_{t+1}\left(x^{t+1}, q^{t+1}\right)}{D_{t}\left(x^{t}, q^{t}\right)} \\
& \times\left\{\frac{D^{I}\left(x^{t+1}, q^{t+1} / D_{t+1}\left(x^{t+1}, q^{t+1}\right)\right)}{D^{I}\left(x^{t}, q^{t} / D_{t}\left(x^{t}, q^{t}\right)\right)}\right\} \\
& \times\left\{\frac{D^{G}\left(x^{t+1}, q^{t+1} / D^{I}\left(x^{t+1}, q^{t+1}\right)\right)}{D^{G}\left(x^{t}, q^{t} / D^{I}\left(x^{t}, q^{t}\right)\right)}\right\}
\end{aligned}
$$

This formula allows us to compute the global Malmquist TFP index and its components by solving linear programming problems. Oh and Lee (2010) constructed six linear programming problems to determine the value of distance functions:

$D_{t}\left(x^{t}, q^{t}\right), D_{t+1}\left(x^{t+1}, q^{t+1}\right), D^{I}\left(x^{t}, q^{t} / D_{t}\left(x^{t}, q^{t}\right)\right), D^{I}\left(x^{t+1}, q^{t+1}\right.$ / $\left.D_{t+1}\left(x^{t+1}, q^{t+1}\right)\right), D^{G}\left(x^{t}, q^{t} / D^{I}\left(x^{t}, q^{t}\right)\right), D^{G}\left(x^{t+1}, q^{t+1} / D^{I}\left(x^{t+1}\right.\right.$, $\left.q^{t+1}\right)$ ), and from the traditional DEA approach we used these distance functions to measure technical efficiency (Coelli, 1996).

\section{Data}

In this study, Vietnamese garment firms are divided into three groups based on ownership including: State-owned, 
private and FDI garment firms. Data used in the study are collected from the survey conducted by Vietnam General Statistics Office (GSO) from 2013 to 2018. A sample consisting of 1754 garment firms is considered in this research, including 50 state-owned garment firms, 594 FDI garment firms and 1110 private garment firms.

To estimate productivity growth of garment firms as well as their components by meta-frontier approach, this study uses added value (VA) as the unique output, which is the sum of Fixed Assets Depreciation, Total Employee Income, Profit and Indirect Taxes. Two inputs are labour (L) and capital (K). $\mathrm{L}$ is the average number of employees in a year, which is calculated as the average of the number of employees at the beginning of the year and at the end of the year for each firm. $\mathrm{K}$ is the average value of firm total assets at the beginning and at the end of year for each firm. Table 1 summarizes descriptive statistics for three groups of the garment industry in the period from 2013 to 2018 .

\section{Empirical Results}

Based on the models proposed by Oh and Lee (2010) and the data of garment firms provided by the GSO, global Malmquist TFP index is estimated for the whole industry as well as its components including TEC, BPC and TGC. Table 2 gives information on TFP index growth and its components of the Vietnamese garment industry from 2013 to 2018 in different types of ownership. The results reveal that the productivity of garment state-owned firms decreases in the years 2014, 2016 and 2017. Private firms' productivity gain is recorded in 2016, 2017. Regardless of ownership types, all firms achieve a substantial growth of productivity in 2018.

Table 1: Data summary for value added and inputs of Vietnamese garment firms in the period 2013-2018

\begin{tabular}{|l|l|c|c|c|c|}
\hline & \multicolumn{1}{|c|}{ Variable } & Mean & Std.Dev & Min & \multicolumn{1}{c|}{ Max } \\
\hline \multirow{2}{*}{$\begin{array}{l}\text { State-owned } \\
\text { Garment firms } \\
\text { group }\end{array}$} & VA(million VND) & 27452.2 & 45300.9 & 15.0 & 226620.0 \\
\cline { 2 - 6 } & K(million VND) & 36528.1 & 66364.0 & 250.0 & 313148.0 \\
\cline { 2 - 6 } & L(person) & 318.2 & 457.1 & 30.0 & 1986.0 \\
\hline \multirow{2}{*}{$\begin{array}{l}\text { Private Garment } \\
\text { firms group }\end{array}$} & VA(million VND) & 91524.9 & 6472965.0 & 10.0 & 301000000.0 \\
\cline { 2 - 6 } & K(million VND) & 34074.0 & 137278.7 & 215.8 & 3474204.0 \\
\cline { 2 - 6 } & L(person) & 232.8 & 6881.4 & 249.0 & 2572421.0 \\
\hline \multirow{2}{*}{$\begin{array}{l}\text { FDI firms } \\
\text { Garment group }\end{array}$} & VA(million VND) & 108935.9 & 169008.2 & 646.0 & 3917325.0 \\
\cline { 2 - 6 } & K(million VND) & 124009.2 & 246248.9 & 150.0 & 15804.0 \\
\cline { 2 - 6 } & L(person) & 1138.5 & 1474.1 & & \\
\hline
\end{tabular}

Table 2: Meta-frontier Malmquist total factor productivity and its decompositions of garment industry

\begin{tabular}{|c|c|c|c|c|c|}
\hline & Year & TEC & BPC & TGC & TFPC \\
\hline \multirow{6}{*}{$\begin{array}{l}\text { State-owned } \\
\text { Garment firms } \\
\text { group }\end{array}$} & 2013-2014 & 1.0448 & 0.7486 & 1.0301 & 0.8057 \\
\hline & 2014-2015 & 1.0241 & 1.0021 & 1.0417 & 1.0691 \\
\hline & $2015-2016$ & 0.9928 & 0.9965 & 0.9963 & 0.9856 \\
\hline & 2016-2017 & 1.0195 & 1.0088 & 0.7867 & 0.8091 \\
\hline & $2017-2018$ & 0.9639 & 1.1798 & 1.2025 & 1.3674 \\
\hline & Mean & 1.0090 & 0.9872 & 1.0114 & 1.0075 \\
\hline \multirow{6}{*}{$\begin{array}{l}\text { Private Garment } \\
\text { firms group }\end{array}$} & 2013-2014 & 1.0845 & 0.9486 & 1.0034 & 1.0322 \\
\hline & 2014-2015 & 1.0142 & 1.1250 & 0.9990 & 1.1398 \\
\hline & $2015-2016$ & 1.0193 & 0.9411 & 0.9925 & 0.9521 \\
\hline & $2016-2017$ & 0.8098 & 1.0047 & 1.0088 & 0.8207 \\
\hline & 2017-2018 & 1.1342 & 1.5737 & 0.9976 & 1.7806 \\
\hline & Mean & 1.0124 & 1.1186 & 1.0002 & 1.1328 \\
\hline \multirow{6}{*}{$\begin{array}{l}\text { FDI firms } \\
\text { Garment group }\end{array}$} & 2013-2014 & 0.9892 & 0.9839 & 1.0211 & 0.9938 \\
\hline & 2014-2015 & 1.0391 & 1.0215 & 1.0356 & 1.0992 \\
\hline & $2015-2016$ & 0.9853 & 0.9619 & 1.0024 & 0.9500 \\
\hline & 2016-2017 & 0.9540 & 1.1443 & 0.7798 & 0.8513 \\
\hline & $2017-2018$ & 1.0638 & 0.9080 & 1.2029 & 1.1620 \\
\hline & Mean & 1.0063 & 1.0039 & 1.0084 & 1.0187 \\
\hline
\end{tabular}


Table 3: Meta-frontier Malmquist total factor productivity and its decompositions of garment industry

\begin{tabular}{|l|c|c|c|c|}
\hline Type of firms & TEC & BPC & TGC & TFPC \\
\hline State-owned garment firms & 1.0090 & 0.9872 & 1.0114 & 1.0075 \\
\hline Private garment firms & 1.0124 & 1.1186 & 1.0002 & 1.1328 \\
\hline FDI garment firms & 1.0063 & 1.0039 & 1.0084 & 1.0187 \\
\hline Mean & 1.0092 & 1.0366 & 1.0067 & 1.0530 \\
\hline
\end{tabular}

Table 4: Technological gap ratio (TGR) summary in Vietnamese garment industry

\begin{tabular}{|l|c|c|c|c|}
\hline Type of firms & Mean & S.D & Min & Max \\
\hline State-owned garment firms & 0.8180 & 0.0390 & 0.7440 & 0.9810 \\
\hline Private garment firms & 0.9970 & 0.0160 & 0.9845 & 1.0000 \\
\hline FDI garment firms & 0.9215 & 0.0300 & 0.8760 & 1.0000 \\
\hline
\end{tabular}

Table 3 gives empirical evidence on the average productivity change of Vietnamese garment industry and all its components. The results show a growth of the industry productivity at a rate of $5.3 \%$ annually. Garment private firms achieve the highest growth rate of productivity at $13.3 \%$ year, followed by FDI firms with the rate of $1.9 \%$ / year. State-owned firms have the lowest rate of productivity growth at $0.7 \%$ year.

The main contributor to industrial productivity growth is technology when the rate of technical progress is about 3.7\% per year during the period 2013-2018. Private firms have the highest technical progress with the rate of $11.6 \%$ per year while there is a regress of technology occurred in the stateowned sector (-1.13\%/year).

The average technical efficiency change of the sample firms is 0.92 percent per year and this result proposes a good catching up of Vietnamese garment firms when they can utilise their inputs better. The private firms' technical efficiency change is the highest (around 1.24\%/year) while this component change of FDI firms is lowest $(0.62 \%$ / year). It is clear that private firms are the major source of productivity growth in Vietnamese garment industry.

The measure of how much a firm gets closer or far away from the industry meta-frontier technology, i.e., TGC, average around $0.67 \%$ per year. It is interesting that stateowned firms are getting closer to the industry frontier at the rate of $1.1 \%$ annually, higher than other two groups (private and FDI group). This finding reveals that even being located furthest from the global frontier compared with other firms, but state-owned firms try to reduce the technology gap.

Generally speaking, in the sectors of private and FDI firms all components (TEC, BPC and TGC) contribute to productivity growth. In the context of state-owned firms, a regress of technology is recorded and seen as the main factor curbing the growth of these enterprises' performance.
The results of the technological gap ratio (TGR) in Table 4 shows which firm group locates nearest the meta-frontier in a relative comparison with other groups. The results advocate the leading position of private firms when located closest to the meta-frontier, with the rate of TGR standing at 0.997 while the similar estimates are 0.9215 and 0.818 for FDI and state-owned groups respectively. The results of BPC and TGR show that private firms are the most technologically innovative and this group contributes substantially to the development of Vietnamese garment industry. Meanwhile, the state-owned firms are the most backward and locating furthest from the meta-frontier.

\section{Conclusion}

Using the meta-frontier approach and DEA, this study investigates the productivity change of Vietnamese garment industry and its components. The results show a growth of productivity and advocate the role of private sector in contributing to this success. The state-owned firms are the most backward in a comparison with other two firm types including private and FDI firms.

A number of policies are proposed to further enhance the performance of Vietnamese garment industry based on the findings in this research. Firstly, the privatisation of stateowned firms should be stimulated in order to transfer their assets to the private and foreign sector. The state-owned firms are proven to be underperformed and keeping the state ownership in the garment industry is a waste of capital and other resources such as land and labour. Secondly, despite the fact that technological progress is the main contributor to the productivity growth, technology should be further innovated to strengthen the industry's competitiveness. It is widely accepted that the 4.0 industrialisation will impact all industries and especially in labour-intensive areas. 
Consequently, the more innovative technology can be applied in production, the higher productivity an industry can achieve.

\section{References}

Alexandra, K., \& Kostas, T. (2010). Are cooperatives the weakest link in European banking? A non-parametric metafrontier approach. Journal of Banking \& Finance, 34(8), 1946-1957. https://doi.org/10.1016/j.jbankfin.2010.01.003.

Battese, G. E., \& Rao, D. S. P. (2002). Technology gap, efficiency, and a stochastic metafrontier function. International Journal of Business and Economics, 1(2), 87-93.

Battese, G. E., Rao, D. S. P., \& O’Donnell, C. J.(2004). Ametafrontier production function for estimation of technical efficiencies and technology gaps for firms operating under different technologies. Journal of Productivity Analysis, 21(1), 91-103. https://doi.org/10.1023/B:PROD.0000012454.06094.29

Coelli, T. J. (1996). A guide to DEAP version 2.1: A data envelopment analysis (computer) program. CEPA Working Paper 96/8. Armidale, Australia, Department of econometrics, University of New England.

Hayami, Y., \& Ruttan, V. W. (1970). Agricultural productivity differences among countries. The American Economic Review, 60(5), 895-911.

Hayami, Y. (1969). Sources of agricultural productivity gap among selected countries. American Journal of Agricultural Economics, 51(3), 564-575.

Ho, D. B. (2016). Analysis of technical efficiency and total factor productivity. Hanoi, Vietnam: Hanoi National University Press.

Le, Q. T. T., Doan, T. H. D., Nguyen, Q. L. H. T. T., \& Nguyen, D. T. P. (2020). Competency Gap in the Labor Market: Evidence from Vietnam. Journal of Asian Finance, Economics and Business, 7(9), 697-706. http://doi.org/10.13106/jafeb.2020. vol7.no9.697

Ministry of Industry and Trade. (2019). Vietnam import and export report 2018. Hanoi, Vietnam: Industry and Trade Press.

Ngo, C., \& Tarko, V. (2018). Economic development in a rentseeking society: Socialism, state capitalism and crony capitalism in Vietnam. Canadian Journal of Development
Studies, 39(4), 481-499. https://doi.org/10.1080/02255189.20 18.1467831

Nguyen, H. M., Bui, N. H., \& Vo, D. H. (2019). The Nexus between Economic Integration and Growth: Application to Vietnam. Annals of Financial Economics, 14(3), 1-16. http:// doi.org/10.1142/S2010495219500143

Nguyen, T. L. (2020). Determinants of Talent Retention in Textile and Garment Companies in Binh Duong Province. Journal of Asian Finance, Economics, and Business, 7(6), 475-484. http:// doi.org/10.13106/jafeb.2020.vol7.no6.475

Nguyen, V. T. H., Hoang, T. T. T., \& Nguyen, S. M. (2020). The Effect of Trade Integration on Business Cycle Synchronization in East Asia. Journal of Asian Finance, Economics and Business, 7(8), 225-231. http://doi.org/10.13106/jafeb.2020. vol7.no8.225

O’Donnell, C. J., Rao, D. S. P., \& Battese, G. E. (2008). Metafrontier frameworks for the study of firm-level efficiencies and technology ratios. Empirical Economics, 34(2), 231-255. https://doi.org/10.1007/s00181-007-0119-4

Oh, D. H., \& Lee, J. D. (2010). A metafrontier approach for measuring Malmquist productivity index. Empirical Economics, 38(1), 47-64. https://doi.org/ 10.1007/s00181-009-0255-0

Pastor, J. T., \& Lovell, C. A. K. (2005). A global Malmquist productivity index. Economics Letters, 88(2), 266-271. https:// doi.org/10.1016/j.econlet.2005.02.013

Quan, N. M. (2011). Using metafrontier and metatechnology ratio tools to expand data envelopment analysis model in productivity and efficient evaluation. Can Tho University's Journal of Scientific Research, 18 (1), 210-219.

Rao, D. S. P., \& Coelli, T. J. (2003). Total factor productivity growth in agriculture: A Malmquist index analysis of 93 countries. 1980-2000, CEPA Working Paper 02/2003. Armidale, Australia, School of economics, University of New England.

Tran, A. N. (2012). Vietnamese textile and garment industry in the global supply chain: State strategies and workers' responses. Institutions and Economies, 4(3), 123-150.

Wang, Q., Zhao, Z., Zhou, P., \& Zhou, D. (2013). Energy efficiency and production technology heterogeneity in China: A metafrontier DEA approach. Economic Modelling, 35(C), 283-289. https://doi.org/10.1016/j.econmod.2013.07.017 